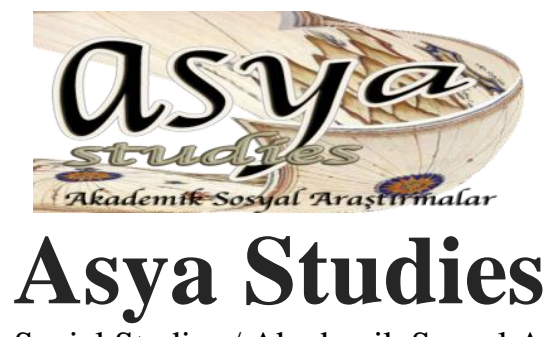

Academic Social Studies / Akademik Sosyal Araştırmalar

Year: 5 - Number: 15, p. 113-127, Spring 2021

\title{
Journal of ETA Maritime Science Dergisinin Bibliyometrik Analizi Bibliometric Analysis of Journal of ETA Maritime Science
}

DOI: https://doi.org/10.31455/asya.881361

\author{
Araştırma Makalesi / \\ Research Article \\ Makale Geliş Tarihi / \\ Article Arrival Date \\ 16.02.2021
}

Makale Kabul Tarihi /

Article Accepted Date

20.03.2021

Makale Yayın Tarihi /

Article Publication Date

31.03.2021

\section{Asya Studies}

Dr. Öğr. Üyesi Murat Yorulmaz Kocaeli Üniversitesi, Denizcilik Fakültesi, Denizcilik İşletmeleri Yönetimi Bölümü

murat.yorulmaz@kocaeli.edu.tr

ORCID ID

https://orcid.org/0000-0002-5736-9146

Sorumlu yazar (Corresponded author);

Serkan Barış

Yüksek Lisans Öğrencisi, Kocaeli Üniversitesi, Fen Bilimleri Enstitüsü, Deniz Ulaştırma ABD srrbrss@gmail.com

\section{ORCID ID}

Öz

Bu çalışmada, The Journal of ETA Maritime Science dergisinde 2013 yılından 2020 yılının 2. sayısına kadar yayımlanan, hakem denetimli makaleler bibliyometrik özellikleri açısından incelenmiştir. Denizcilik alanına yaptığı yayımlarla katkıda bulunan dergi, 2016 yılına kadar yılda 2 sayı yayımlarken, 2016 yilında ve sonrasında yılda 4 sayı yayımlamaktadır. Araştırma kapsamında hakem denetimli yayınlanmış 153 makaleye ait veriler, Excel programına aktarılmıştır. Excel' de oluşturulan konu başlığına göre 17 sutun oluşturulmuştur. Her bir makaleden elde edilen bilgiler bu başlıklar altında sınıflandırılmıştır. Toplanan bu bilgilerden yine Excel yardımıyla hesaplamalar yapılmış, grafikler ve tablolar oluşturulmuştur. Bunun yanında Maxqda 2020 programı kullanılarak, Excel üzerinde toplanan veriler bu programa aktarılmış ve makale başlıklarının kelime frekans tablosu çıkarılıp, kelime bulutu oluşturulmuştur. Yapılan incelemeler sonucunda; yıl bazında en fazla makale 29 adet çalışma ile 2017 yılında yayımlanmıştır. Yıllık ortalama yayınlanan makale sayısı 19,15'dir. Yayınlanan makalelerin \%57'si Türkçe, \%43'ü İngilizce'dir. Makalelerin ortalama sayfa sayısı 12,4 iken; makakalelerin en uzunu 25 sayfa, en kisası 2 sayfadır. Makalelerin ortalama kaynakça sayısı 26,9'dur. Toplam 363 yazardan; 283'̈̈ erkek, 60'ı kadındır. En fazla yayın yapan kurum 82 yazarla Dokuz Eylül Üniversitesi'dir. Makale yazarlarının \%87,98'i Türk üniversitelerinde görev yapmaktadır. Konu başlıklarına göre makaleler incelendiğinde, 37 makaleyle en fazla Gemi Makineları alanında makale yazılmıştır. Makalelerin \%60'ında nicel, \%29'unda nitel ve \%11'inde karma araştırma yöntemi kullanılmıştır. Makale başlıklarının kelime frekansı incelendiğinde, derginin amacı bakımından en yüksek frekansa "Gemi" kelimesi sahipken, kapsam bakımından en yüksek frekansa "Analizi” kelimesi sahiptir.

Anahtar Kelimeler: Journal of ETA Maritime Science Dergisi; Bibliyometrik Analiz; Denizcilik

\section{Abstract}

In this study, peer-reviewed articles published in The Journal of ETA Maritime Science from 2013 to the 2nd issue of 2020 were examined in terms of their bibliometric features. Journal, published 2 issue until 2016 and then 4 issue in every year, contrubute to the maritime field with its publications. Within the scope of the research, the data of 153 articles published with referee control were transferred to the Excel program. 17 columns were created according to the subject title created in Excel. The information obtained from each article is classified under these titles. From this collected information, calculations were made with the help of Excel, and charts and tables were created. In addition, the data collected on Excel using the Maxqda 2020 program was transferred here and the word frequency table of the article titles was extracted and the word cloud was created. As a result of examine; the most articles on a yearly basis were published in 2017 with 29 studies. The annual avarage published number of article is 19,15. Considering the articles' language, 57 percent of articles are published in Turkish, 43 percent in English. While the average number of page of article is 12,4; the longest articles is 25 pages, the shortest is 2 pages. Average number of citations for articles is 26,9. Totally, there are 343 authors who are 283 man, 60 women. Dokuz Eylül University became as the most publishing institutions by 82 authors. 87,98 percent of authors serve in Turkish universities. If we categorize the articles according to their subject titles, most articles were written in the field of Marine Engineering with 37 articles. The quantitative method was used in 60 percent of the articles, qualitative in 29 percent and mixed research method in 11 percent. When the word frequency of article titles is examined, the word "Ship" has the highest frequency for the purpose of the journal, while the word "Analysis" has the highest frequency in terms of scope.

Keywords: Journal of ETA Maritime Science; Bibliometric Analysis; Maritime

\section{Citation Information/Kaynakça Bilgisi}

Yorulmaz, M. ve Barış, S. (2021). Journal of ETA Maritime Science Dergisinin Bibliyometrik Analizi. Asya Studies-Academic Social Studies / Akademik Sosyal Araştırmalar, 5(15), 113-127. 


\section{GİRIS}

Dergi, makale ve kitap gibi yayınlanmış olan çalışmaların matematiksel ve istatistiksel yöntemler kullanılarak incelendiği çalışmalara bibliyometrik çalışmalar denir. Bilimsel inceleme tekniği olan bibliyometriyi 1969 yılında ilk kez ortaya atan kiși Pritchard'tır (Kayakıran ve Doğan, 2019). Bibliyometrik analiz çalışmalarında üzerinde çalışma yapılan yayınların özellikleri belirli konularda analiz edilerek bilimsel bulgulara ulaşılır (Karagöz ve Ardıç, 2019). Yapılan bibliyometrik çalışmalar, çalışma yapılan bilim alanındaki gelişim seviyesini, çalışmada odaklanılan noktaları, çalışma alanının gelişmiş ve gelişmesi gereken noktaların tespit edilmesini sağlamaktadır. Bibliyometrik analiz sayesinde bir alana ait yayınlanmış olan kaynakların gelişmişlik düzeyini tespit edebiliriz (Hotamışlı ve Erem, 2014).

Bibliyometrik analiz çalışmalarında yazarlarla ilgili cinsiyet, yazar sayısı, çalıştıkları kurum bilgisi gibi yazarlarla ilgili bilgilerin istatistiksel incelemesinin yanı sıra; kaynaklar ve çalışmaların sınıflandırılması gibi verilerin istatistiksel açıdan incelenmesinin sonucunda disipline bir çerçevede genel bir yapı ortaya koyarak bulgular elde etmiş oluruz. Bu araştırma yöntemiyle yayınlarla ilgili bulguları elde edebiliriz (Bozkurt ve Çetin, 2016). Bibliyometrik çalışmalarda, incelenen kurumun, bilim dalının ve ülkenin bulguları çalışmalar ışığında incelenerek; yapmış oldukları ilerlemeler ve geçirmiş oldukları aşamalar görülüp, geleceğe yönelik değerlendirmeler yapılabilmektedir (Şakar ve Cerit, 2013).

Türkiye'de denizcilik alanında yayın yapan akademik dergiler içerisinde Web of Science listesine giren tek denizcilik dergisi Journal of ETA Maritime Science (JEMS) Dergisi'dir. Dergiyle ilgili daha önce yapılan "Journal of ETA Maritime Science (JEMS) Dergisinin Nitel Analizi ve Yönetim Süreci" isimli çalışmada 2012-2016 yıllarında arasında yayımlanan 52 adet makalenin incelemesi yapılmıştır. $\mathrm{Bu}$ makalelerin katogorileri, istatiki ve tip bilgileri ile hakem bilgileri üzerine çalışma yapılarak, çalışma sonucunda veriler paylaşılmıştır. Bu çalışmanın dışında, JEMS dergisi ile ilgili yapılan herhangi başka bir çalışma yoktur. Yapılan bu çalışma sınırlı bir nitel analiz çalışması olduğu için daha detaylı bir bibliyometrik analiz çalışması yapılmasına ihtiyaç olduğu düşünülürek, JEMS dergisinin bibliyometrik analizi yapılmıştır.

2013 yılında yayın hayatına başlayan JEMS dergisi, ULAKBIM TR Dizin, Directory of Open Access Journals (DOAJ), Index-Copernicus indeks listesinde yer almaktadır (Fışkın ve Nas, 2016). Bu indekslerin yanı sıra son olarak Web of Science indeks listesinde yer almıştır. JEMS Dergisi, Türkiye'de yayımlanan ve Web of Science indeks listesinde yer alan ilk denizcilik dergisi olmayı başarmıştır.

Derginin sahibi olarak yayınlanmasını sağlayan kuruluş TMMOB Gemi Makineleri Mühendisleri Odası'dır. Derginin amacı, denizcilik sektöründeki araştırma çalışmalarını destekleyip, yayınlamaktır. Bunun yanında, bilimsel ve teknolojik gelişmelerle ilgili yapılan son bilimsel çalışmaları ilgili kitlelere ulaştırmayı amaçlamıştır. JEMS dergisi düzenli olarak yılda 4 defa yayınlanmaktadır. Derginin içeriğinde; Deniz Mühendisliği, Denizcilik İşletmeleri Yönetimi, Deniz Ulaştırma Mühendisliği, Gemi İnşaa Mühendisliği, Denizcilik Operasyonları, Lojistik, Lojistik Mühendisliği, Denizcilik Tarihi, Kıyı Mühendisliği, Deniz Kirliliği ve Çevre, Balıkçılık ve Balıkçılık Teknolojisi, Gemi İnşa ve Okyanus Mühendisliği ile ilgili ulusal ve uluslararası çalışmalar yer almaktadır. Derginin yönetimi, deneyimli akademisyenler tarafından yürütülmektedir (Fışkın ve Nas, 2016). Dergi 2020 yılından itibaren sadece İngilizce olarak yayınlanmaktadır. Dergilere, https://jemsjournal.org/ sitesinde ulaşılabilmektedir.

\section{LITERATÜR İNCELEMESI}

\subsection{Bibliyometrik Çalışmalar}

Literatüre baktığımızda yapılan bibliyometrik çalışmaların başlama tarihi ile ilgili farklı görüşler yer almaktadır. 1896 yılında Campbell tarafindan yayımlanan "Theory of the National and International Bibliography” isimli çalışma Sengupta (1992: 92) tarafından ilk bibliyometrik çalışma olarak kabul edilmektedir. Lawani (1981: 295)'e göre, Cole ve Eales tarafından 1917 yılında yapılan ve 1550 -1860 yılları arasında yayınlanan karşılaştırmalı anatomi alanında yapılan araştırmaların, istatistiki analizini kapsayan çalışma ilk bibliyometrik çalışma olarak kabul edilmektedir (Hotamışlı ve Erem, 2014). 1917 yılında Cole ve Eales tarafından yapılan çalışmanın ardından 1923 yılında E. Wyndham Hulme tarafından da bibliyometrik çalışma yapılmıştır. İngiliz Patent Ofissindeki görevi kütüphanecilik olan Hulme, tarih bilimi ile ilgili istatiki analiz ortaya koymuştur (Bozkurt ve Çetin, 2016).

Ülkemizde, ilk bibliyometrik çalışma 1970 yılında A. Kemal Özinönü tarafından yapılmıştır (Al, 2008). Yapılan bu ilk çalışma "Growth in Turkish Positive Basic Sciences" kitabıdır. Bu bibliyometrik çalışmanın yer aldığı kitapta, Türkiye’ deki kimya, astronomi, biyoloji, matematik, fizik ve yer bilimleri 
ile ilgili yapılan çalışmalarda, bilimsel verimlilik ölçülmüştür (Polat, Sağlam, ve Sarı, 2013). Ülkemizde, 1970’li yıllardan 1990'lı yıllara kadar pek fazla bibliyometrik çalışma görülmemektedir. Ancak 1990’lı yıllardan sonra bibliyometrik çalışmalara duyulan ilginin artması sonuncunda, yayınlanan bibliyometrik çalışma sayısında artış görülmektedir (Al, 2008).

\subsection{Denizcilik Alanı İle İlgili Bibliyometrik Analiz Çalışmaları}

Literatür taraması yaptığımızda, Gdynia Denizcilik Üniversitesi, Seyir Fakültesi tarafından yayınlanan "International Journal on Marine Navigation and Safety of Sea Transportation (TransNav Journal)" dergisinin Türk akademisyenler Fışkın ve Nas tarafından içerik analizinin yapıldığ 1 karşımıza çıkmaktadır. Bu dergide 2007 yılından başlayıp 2012 yılına kadar yayınlanmış 401 adet akademik makalenin incelemesi yapılarak, makale yazarlarının çalıştıkları kurumlar ile dergiye sağladıkları katkılar analiz edilmiştir (Fışkın ve Nas, 2013).

World Marime University Journal of Marime Affairs (JOMA) denizcilikle alakalı uluslararası araştırmaların yayınlandığı bir dergidir. 2020 yılında Sahoo ve Schönborn tarafından 2002 y1lından 2020 yılına kadar yayınlanan tüm dergilerin bibliyometrik analizi yapılmıştır. Yapılan analizde, yapılan atıf sayıları, yazarların bağlı görev yaptıkları üniversitlerin, yazarların ülkeleri ve yazıların konu başlıkları gibi birçok kriter değerlendirilmiştir. Yapılan araştırmanın amacı derginin gelecekte denizcilik sektörüne katkıda bulunabilmesi için nasıl bir yol izlemesi gerektiğini göstermektir (Sahoo ve Schönborn, 2020). Bu çalışma, uluslararası yayın yapan denizcilik dergilerinin bibliyometrik analizi ile ilgili yapılan en son çalışmalardan biridir.

Denizcilikle ilgili yakın zamanda yapılan çalışmalara örnek olarak, Fışkın ve Cerit tarafından 2020 yılının mart ayında Scientific Journals of the Maritime University of Szczecin dergisinde yayınlanan "Comparative Bibliometric and Network Analysis of Maritime Transport/Shipping Literature Using the Web of Science Database" başlıklı bibliyometrik çalışmayı örnek gösterebiliriz. Bu çalışmada Web of Science veritabanında 1978 ile 2018 yılının Kasım ayına kadar deniz taşımacışı̆̆ı ve denizcilik ile ilgili yayımlanan bilimsel çalışmaların literatür taraması ile ilgili bibliyometrik analizi yapılmıştır (Fışkın ve Cerit, 2020).

JEMS Dergisi'nin 2016 yılının 4. sayısında yayımlanan “A Qualitative Analysis of Journal of ETA Maritime Science (JEMS) and Its Management Process” isimli çalışmada 2012-2016 yılları arasında JEMS Dergisi'nde yer alan 52 makale incelenmiştir. Sınırlı olarak nitel analizin yapıldığı bu çalışmadan başka JEMS Dergisi'nin bibliyometrik analizi ile ilgili herhangi bir çalışma bulunmamaktadır.

\subsection{The Journal of ETA Maritime Science Dergisinde Makale Yayınlanma Așamaları}

Dergilerin bilimsel performansını ölçmede kullanılan etki faktörü dergide yayınlanan makaelerdeki atıf sayısıyla ölçülür. Etki faktörünün yüksek olması o derginin değerli olduğunu gösterir (Ertekin, 2014).

JEMS'e gönderilen makaleler, yazarlar tarafından mail yoluyla gönderilmelidir. Gönderilen akademik makalelerin öncelikle yazım kurallarına ve yayın alanına uygun olup olmadığı editörlerce kontrol edilir. Ayrıca, makalelerin intihal kurallarına uygun olup olmadığı editörler tarafindan kontrol edilir. Bölüm editörleri yazılan metinleri değerlendirilmesi için en az iki hakem belirlemek zorundadır. Makaleler değerlendirilirken Türkçe karşılığı çift kör hakem değerlemdirmesi olan 'Double Blind Review' tekniği kullanılmaktadır (Fışkın ve Nas, 2013). Çift Kör Hakem Tekniğinde, yazarlar ve hakemlerin kimlikleri gizli tutulmaktadır. Hakem, yazıyı değerlendirirken yazının kime ait olduğunu bilmeden değerlendirir (Snodgrass, 2007). Belirlenen bu hakemlerden ikisi de makaleyi geri çevirirse makale kabul görmemiş olur. Eğer iki hakemden de geçer yada düzeltme alırsa, yazar tarafindan düzeltmesi yapıldıktan sonra bölüm editörünün kontrolüne gönderilir. Eğer hakemlerden biri kabul etmeyip, diğeri düzeltme vermiş ise makale başka bir hakem tarafindan incelenir. Bu hakem düzeltme verirse makale editör kontrolüne gidebilir ancak geri çevirirse makale kabul görmemiş olur. Bu değerlendirmelerden sonra editör kontrolünden geçen makale dil editörüne gönderilir. Makale, son olarak dil editörünün kontrolünden geçtikten sonra yayınlanması için hazır hale gelmiş olur (Fışkın ve Nas, 2013). 


\section{ARAŞTIRMA YÖNTEMI}

\subsection{Veri Toplanma Araçları}

Dergi yayın hayatına 2013 yılında başlamışıtır. İlk sayısından itibaren 2020 yılının 2. Sayısına kadar yayınlanan dergilerde yer alan 153 makale bibliyometrik göstergelerle incelenmiştir. 2020 yllının 2. sayısına kadar incelenmesinin nedeni ise dergi 2020 yılının 1. sayısından sonra Web of Science the Emerging Source Citation Index (ESCI) veritabanında yayınlanmaya başlaması olup, yayınlanmaya başlamadan önceki çalışmalar incelenmiştir. Derginin arşiv bölümüne elektronik ortamda girildikten sonra daha önce yayınlanan 23 adet dergiye ve bu dergiler içinde yer alan toplam 153 adet makaleye PDF formatında ulaşılmıştır. Belirlenen 13 parametrenin doğrultusunda, ulaşılan makalelerin verileri toplanmıştır.

Bibliyometrik analizi gerçekleştirmek için belirlenen parametreler şunlardır;

- Y1llara göre makale sayısı

- Y1llara göre yayınlanan dergi sayısı

- Makale sayfa sayis1

- Makalelerde kullanılan dil

- Makalelerde kullanılan kaynakça sayısı

- Yazar sayısı ve cinsiyetlere göre dağılımı

- Yazarların çalıştıkları kurumlar

- Yazarların unvanları

- Dergide ödüllendirilen yazarlar

- Makalelerin konu başlıklarına göre dağılımı

- Yıllara bağlı çalışma konularındaki eğilim

- Makalelerin araştırma yöntemleri

- Makale başlıklarının kelime frekansları

\subsection{Verilerin Analizi}

Makalelerden toplanan verileri analiz etmede kullanılacak yöntem bibliyometrik analiz yöntemidir. Bibliyometrik analiz, bibliyometrik göstergeleri kullanarak akademik yayınları çözümlemeye yarayan bir yöntemdir (Karagöz ve Koç Ardıç, 2019).

Araştırma kapsamında hakem denetimli yayınlanmış 153 makaleye ait veriler, Excel programına aktarılmıştır. Excel' de oluşturulan konu başlığına göre 17 sütun oluşturulmuştur. Her bir makaleden elde edilen bilgiler bu başlıklar altında sınıflandırılmıştır. Toplanan bu bilgilerden yine Excel yarımıyla hesaplamalar yapılmış, grafikler ve tablolar oluşturulmuştur. Bunun yanında Maxqda 2020 programı kullanılarak Excel üzerinde toplanan veriler buraya aktarılmış ve makale başlıklarının kelime frekans tablosu çıkarılıp, kelime bulutu oluşturulmuştur. $\mathrm{Bu}$ yöntemlerle çalışmanın nesnel bir çizgide tamamlanmasına çalışılmıştır.

\section{BULGULAR}

Bu bölümde, JEMS Dergisi'nde 2013-2020 yıllarında yayınlanmış 153 adet akademik makalenin veri analizi sonucunda elde edilen siralama, tablo, grafik, yüzde ve kelime frekans analiz sonucunda yapılan değerlendirmeler ve bulgular yer almaktadır.

\subsection{Yıllara Göre Yayımlanan Makale Sayısı}

2013-2020 yılları arasında yayımlanan toplam makale sayısı 153'tür. 2016 ve sonraki yıllarda yayımlanan makale sayısında yüksek oranda artış görülmüsstür. Makale sayısının yıllara göre dağılımı Şekil 1'de gösterilmiştir. 


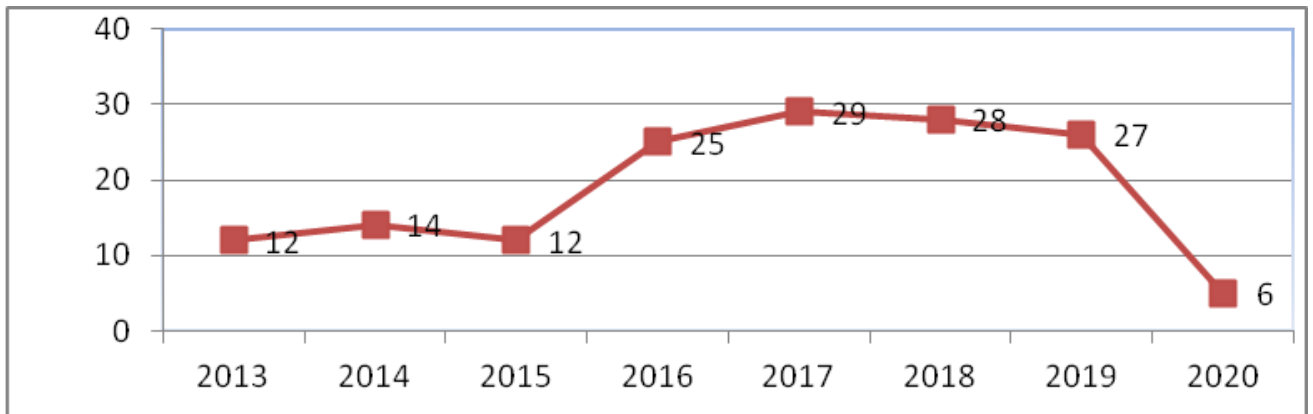

Şekil 1. Yıllara Göre Yayımlanan Makale Sayıları

2016 ve sonraki yıllarda makale sayısında önceki yıllara göre yaklaşık 2 kat artış olduğu görülmüştür. 2020 yılında yayımlanan makale sayısının 5 olmasının nedeni araştırmalarda 2020 yılına ait sadece ilk derginin verilerinin kullanılmasındandır. 2013-2020 y1llarında yayımlanan makalelerin yıllık ortalaması 19,15 makale/yıl yapmaktadır. 2013, 2014 ve 2015 yıllarında bu ortalamanın altında kalırken, bundan sonraki yıllar bu ortalamanın üstündedir.

\subsection{Yıllara Göre Yayımlanan Dergi Sayısı}

2013 yılında çıkarılmaya başlayan derginin, 2020 yılının 2 sayısına kadar toplamda 23 adet sayısı bulunmaktadır. 2013, 2014 ve 2015 yıllarında yılda 2 dergi yayımlanırken, daha sonraki yıllarda yılda 4 dergi yayımlamıştır. Dergi sayısındaki artış, yayımlanan makale sayısını arttırmıştır.

\subsection{Yayımlanan Makalelerin Sayfa Sayıları}

2013-2020 yılları arasında JEMS dergisinde yayımlanan makalenin yıllara göre sayfa sayısı dağılımı Tablo 1'den incelendiğinde, en yüksek sayfa sayısının 2017 yılında 422 sayfa olduğu görülmektedir. İlk sayısından 2020 yılının 2. sayısına kadar olan tüm makaleler toplamda 1909 sayfadır. Makale ortalama sayfa uzunluğu ise 12,4 sayfadır.

\begin{tabular}{|l|c|c|c|c|c|c|c|c|}
\hline Yillar & $\mathbf{2 0 1 3}$ & $\mathbf{2 0 1 4}$ & $\mathbf{2 0 1 5}$ & $\mathbf{2 0 1 6}$ & $\mathbf{2 0 1 7}$ & $\mathbf{2 0 1 8}$ & $\mathbf{2 0 1 9}$ & $\mathbf{2 0 2 0}$ \\
\hline Sayfa sayis1 & 102 & 128 & 128 & 333 & 422 & 377 & 338 & 81 \\
\hline
\end{tabular}

\section{Tablo 1. Yıllara Göre Makale Sayfa Sayısı}

Çalışmada incelenen makalelerden en kısa yazılan makale 2 sayfa, en uzun yazılan makale 25 sayfadır. Şekil 2'de makalelerin, sayfa sayısına göre 4 farklı gruba ayrıldığı görülmekte ve bu gruplarda bulunan makalelerin yüzdelik oranları verilmektedir.

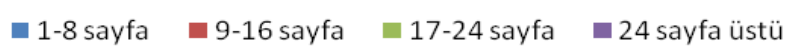

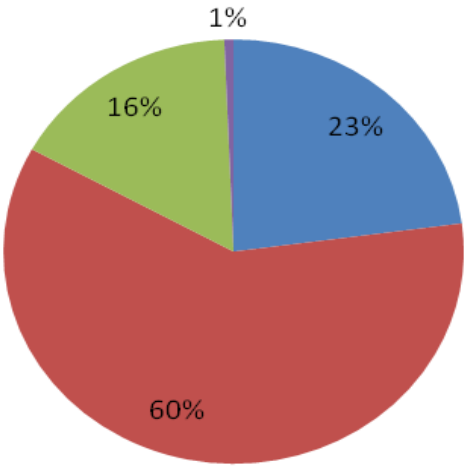

Şekil 2. Sayfa Sayısına Göre Yüzde Oranları 
Araştrımalar sonucu elde edilen verilere göre makalelerin \%60’ının sayfa sayısı en az 9, en fazla 16 sayfadır. Daha sonra sırasıyla; \%23'ünün sayfa sayısı en az 1, en fazla 8 sayfa; \%16'sının sayfa sayısı en az 17, en fazla 24 sayfa ve \%1'inin sayfa sayısının 24'den fazla olduğu görülmektedir.

\subsection{Yayımlanan Makalelerde Kullanılan Yazı Dili}

Journal of ETA Maritime Science Dergisi yazı dili Türkçe ve İngilizce'dir. Çalışma kapsamındaki makalelerin 86'sı Türkçe, 64'ü İngilizce olarak yayımlanmıştır. Oransal olarak \%57'si Türkçe yayımlanırken, \%43'ü İngilizce yayımlanmıştır. Makalelerde yıllara göre kullanılan yazı dili dağılımı Şekil 3 ’te gösterilmiştir.

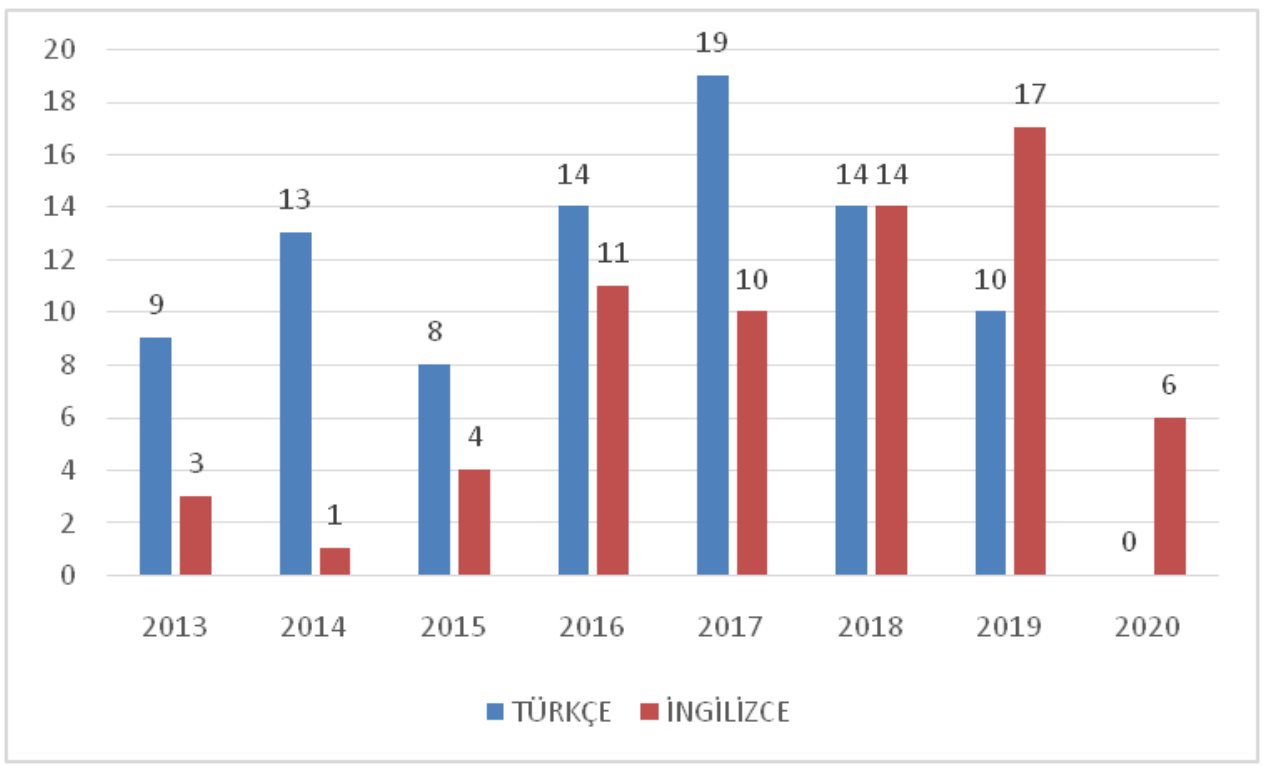

Şekil 3. Yıllara Göre Makalelerde Kullanılan Yazı Dili

Elde edilen verilere göre İngilizce makale en fazla 2019 yılında, en az 2014 yılında yazılmıştır. Türkçe makale sayısı en fazla 2017, en az 2020 yılında yazılmış ve bu yılda hiç Türkçe makale yazılmamıştır. Çünkü dergi 2020 yılı itibari ile komple İngilizce yazı diline geçmiştir.

\subsection{Yayımlanan Makalelerin Kaynakça Sayısı}

Yayımlanan dergiler araştırmaya dayalı akademik makaleler içerdiği için bir makale dışında tüm makaleler kaynakça içermektedir. 2015 yılının 2. sayısında yer alan 'Gemi Finansman Kredi Sözleşmelerinde Değerleme ve Yeniden Değerleme Riski’ başlıklı makale ve "Otomatik Konteyner Terminalleri ve Terminal Yönetim Bilgi Sistemleri” başlıklı kitap eleştirisi kaynakçaya sahip değildir. Ayrıca 2019 yılının 3. sayısında yayımlanan "Better Together" ve 2020 yılının 1. sayısında yayımlanan "Understanding IMO 2020” başlıklı yazılarda kaynakçaya sahip değildir. Bunun dışındaki tüm makaleler kaynakçaya sahiptir. Yapılan çalışmada incelenen makaleler içinde en çok kaynağa sahip makalede 143 kaynak kullanırken, en az kaynağa sahip makale ise 4 kaynak kullanmıştır.

Derginin, 2013 yılından 2020 yılının 2. sayısına kadar yayımlanan tüm makalelerde yıllara göre kullanılan kaynakça sayısı ve makale başına düşen ortalama kaynakça sayısı Tablo 2'de görülmektedir. 


\begin{tabular}{|c|c|c|c|c|c|c|c|c|c|}
\hline Yıllar & $\mathbf{2 0 1 3}$ & $\mathbf{2 0 1 4}$ & $\mathbf{2 0 1 5}$ & $\mathbf{2 0 1 6}$ & $\mathbf{2 0 1 7}$ & $\mathbf{2 0 1 8}$ & $\mathbf{2 0 1 9}$ & $\mathbf{2 0 2 0}$ & Toplam \\
\hline $\begin{array}{c}\text { Kaynak } \\
\text { sayısı }\end{array}$ & 133 & 214 & 369 & 613 & 841 & 980 & 825 & 142 & 4117 \\
\hline $\begin{array}{c}\text { Makale } \\
\text { başına } \\
\text { düşen } \\
\text { ortalama } \\
\text { kaynak } \\
\text { sayısı }\end{array}$ & 11,1 & 14,3 & 30,8 & 24,5 & 29 & 35 & 30,6 & 23,7 & 26,9 \\
\hline
\end{tabular}

Tablo 2. Yıllara Göre Kullanılan Kaynak Sayısı Ve Makale Başına Düşen Kaynak Sayısı

Yıllara göre kaynak en fazla 2018'de kullanılırken, en az kaynak 2013'te kullanılmıştır. İncelenen makalelerde, toplam 4117 kaynak kullanıldığı tespit edilirken, makale başına düşen ortalama kaynak sayısının 26,9 olduğu tespit edilmiştir.

\subsection{Yayımlanan Makalelerin Yazar Sayısı ve Cinsiyetlere Göre Dağılımı} gösterilmiştir.

Yapılan çalışmalar sonucunda, makale yazarlarının yıllara göre cinsiyet dağılımı Şekil 4'te

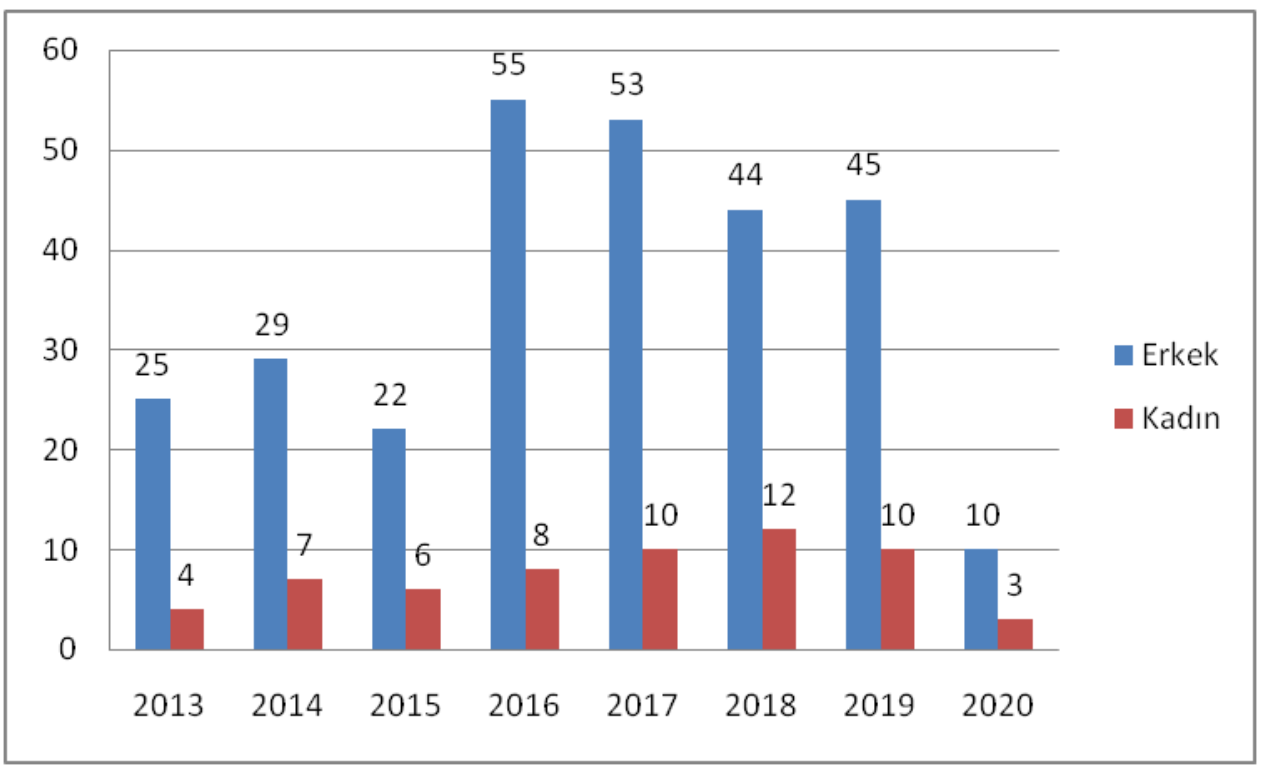

Şekil 4. Yıllara Göre Yazar Sayısı ve Cinsiyetlere Göre Dă̆ılımı

2013-2020 yılları arasında incelemesi yapılan 153 makaleyi toplamda 343 yazar yazmıştır. Makale başına ortalama 2,24 yazar düşmektedir. Yine 2013-2020 yılları arasında yayımlanan toplam 23 dergide, dergi başına düşen yazar sayısı 14,91'dir.

2013-2020 yıllarında erkek yazar sayısı her zaman kadın yazar sayısından fazladır. 12 kadın yazarın olduğu 2018 yılı en fazla kadın yazarın olduğu yıl iken, sadece ilk dergi sayısı incelenen 2020 yılında kadın sayısı 3'tür. 2020 yılını takip eden en az kadın yazar sayısının olduğu yıl, 4 yazar sayısıyla derginin yayınlanmaya başladığı 2013 yılıdır. 


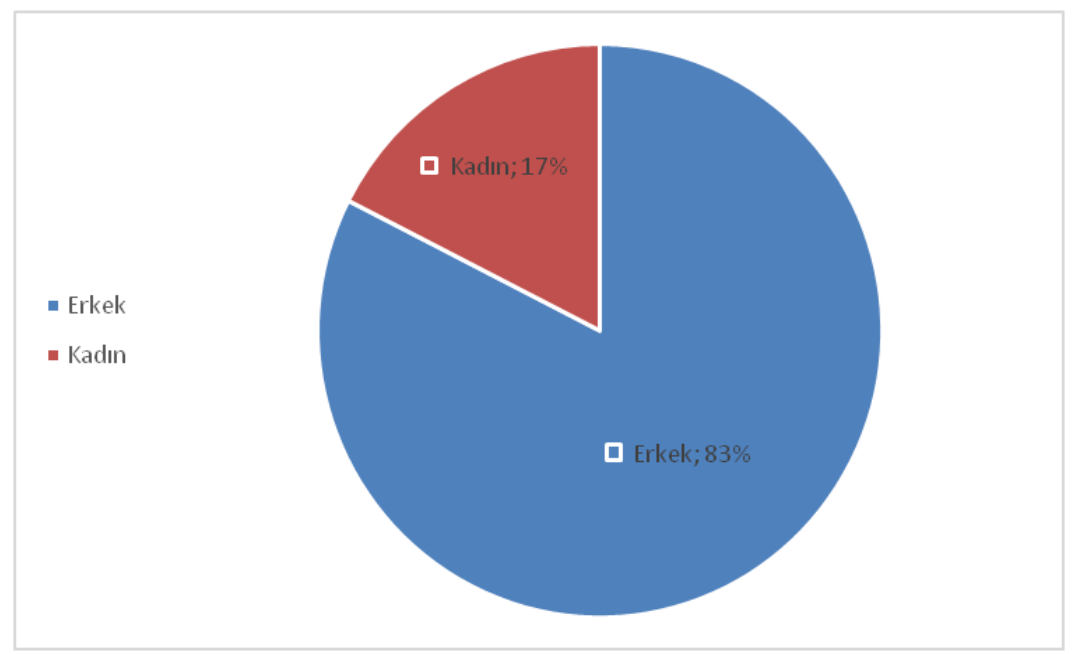

Şekil 5. Cinsiyete Göre Yazar Dağıllım Oranı

İncelenen makalelerdeki toplam 343 yazarın 283'ü erkek, 60’1 kadın yazardır. Makalelerin toplam erkek ve kadın yazar sayılarının oransal olarak verildiği Şekil 5 incelendiğinde, yazarların \%83'ünün erkek, \%17’sinin kadın olduğu görülmektedir.

\subsection{Yayımlanan Makalelerin Yazar Kurumları}

Yapılan incelemede, 2013-2020 yılları arasında JEMS Dergisi'nde yayımlanan 153 makalenin yazarlarının 46 farklı kurumda görev yaptıkları görülmüştür. Şekil 6'da en çok yazarın çalıştı̆ı̆ ilk 5 kurum ve bu kurumlarda çalışan yazar sayıları verilmiştir. En çok yazarın bulunduğu kurum sırasıyla Dokuz Eylül Üniversitesi (82 yazar), İstanbul Teknik Üniversitesi (78 yazar), Yıldız Teknik Üniversitesi (37 yazar), Karadeniz Teknik Üniversitesi (27 yazar) ve Piri Reis Üniversitesi (12 yazar)'dir.

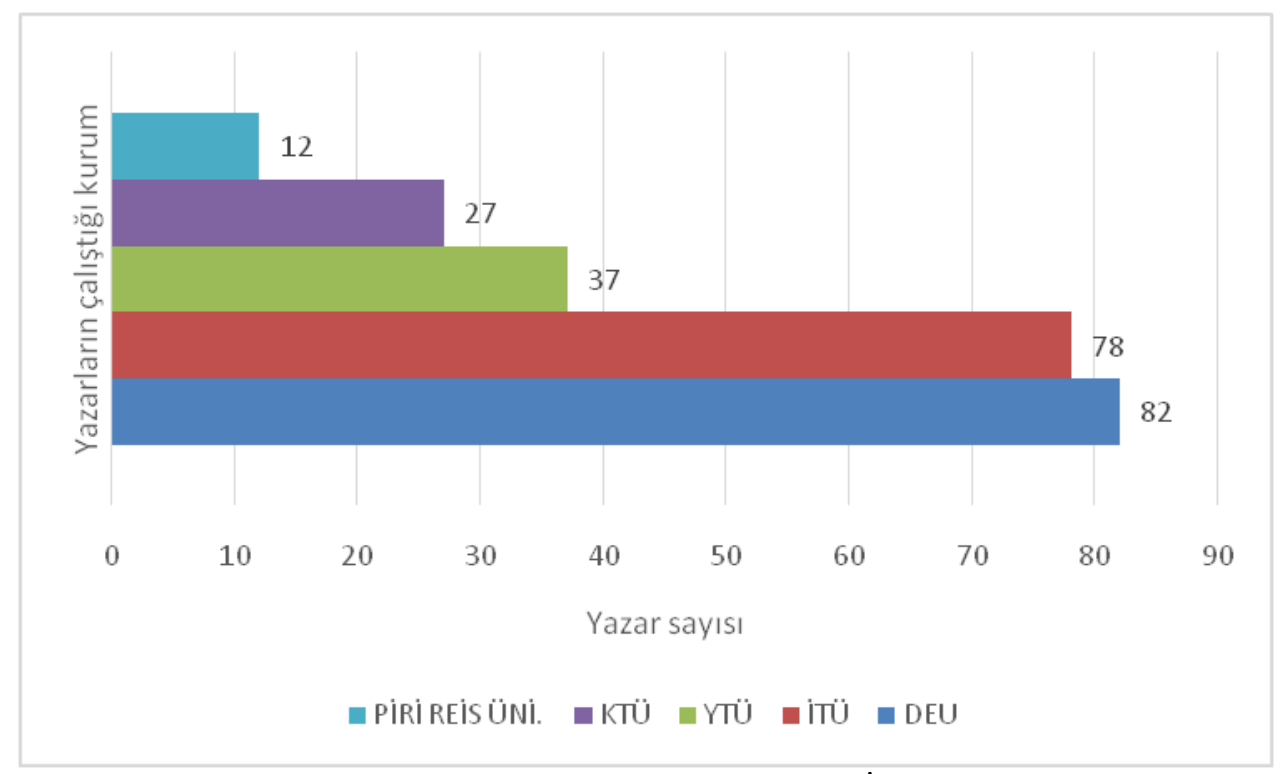

Şekil 6. Yazar Sayılarının En Çok Olduğu İlk 5 Kurum

Yazarların çalı̧̧ıkları kurumlar Türk üniversiteleri, yabancı üniversiteler, özel sektör, dernekler ve kamu kurumları olmak üzere 5 farklı grupta sınıflandırılmıştır. Şekil 7'de yazarların çalıştıkları kurumların yüzdelik oranları verilmiştir. 


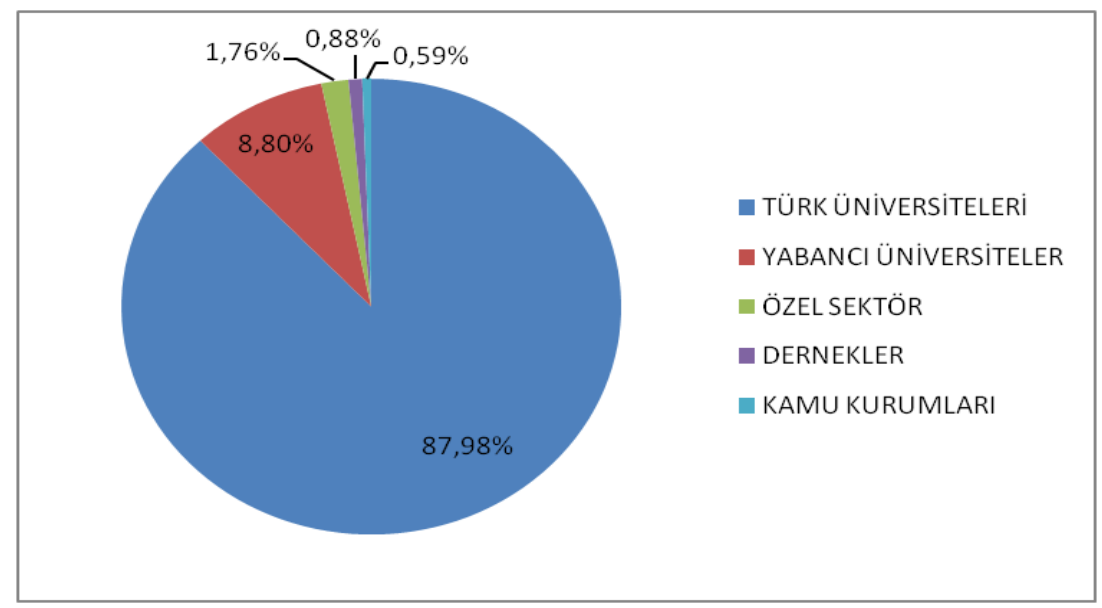

Şekil 7. Yazarların Çalıştıkları Kurum Çeşidi

JEMS Dergisi'nde yazarların \%87,98'i Türk üniversitelerinde görev yaparken, \% 8,80'i yabancı üniversitelerde görev yapmaktadır. En az oranda yazarın görev aldığı kurumlar ise \%0,59 oranında olan derneklerdir.

\subsection{Yayımlanan Makalelerin Yazar Unvanları}

JEMS dergisindeki yazar unvanlarını incelendiğinde, makalelerinde 10 yazarın unvan belirttiğini, bunların dışında kalan diğer yazarların unvan belirtmediği görülmektedir. Derginin 2017 yılının 3. sayısı ve daha sonraki yayınlanan sayılarında yer alan makalelerde yazar "Open Researcher ve Contributor ID (ORCID)" numaralarının yer aldığı görülmüştür.

\subsection{Dergide Ödüllendirilen Yazarlar}

JEMS Dergisi'nde hem makale yazmış hem de hakemlik yapmış yazarlar bulunmaktadır. 2016 ve sonraki yıllarda, yaptıkları hakemlik görevlerinden dolayı bazı yazarlar ödüllendirilmiştir. Dergide, 2020 yılında ödül alan kişiler belirtilmemiştir. Yıllara göre en iyi hakemlik ödülünü alan yazarlar Tablo 3 'te gösterilmiştir.

\begin{tabular}{|c|c|c|c|c|}
\hline Yıllar & \multicolumn{4}{|c|}{ Yazarlar } \\
\hline 2016 & Barış KULEYIN & Jale Nur ECE & Shi HE & $\begin{array}{c}\text { Ceren ALTUNTAŞ } \\
\text { VURAL }\end{array}$ \\
\hline 2017 & Ünal ÖZDEMİR & Aysu GÖÇER & Ayhan MENTEŞ & Kadir ÇİÇEK \\
\hline 2018 & Yusuf ZORBA & $\begin{array}{c}\text { Didem ÖZER } \\
\text { ÇAYLAN }\end{array}$ & - & - \\
\hline 2019 & Onur USTA & Sercan EROL & - & - \\
\hline
\end{tabular}

Tablo 3. Yıllara Göre En Iyi Hakemlik Ödülünü Alan Yazarlar

2016 ve 2017 yılında 4 yazara en iyi hakem ödülü verilirken; 2018 ve 2019 yılında 2 yazara en iyi hakemlik ödülü verilmiştir.

\subsection{Makalelerin Konularına Göre Dağılımı}

JEMS Dergisi'ndeki makaleler Şekil 8'de görüldüğü gibi konularına göre 10 başlık altında sınıflandırılmıştır. Yapılan bu sınıflandırma başlıkları, derginin editörleri tarafından belirlenmiştir. 


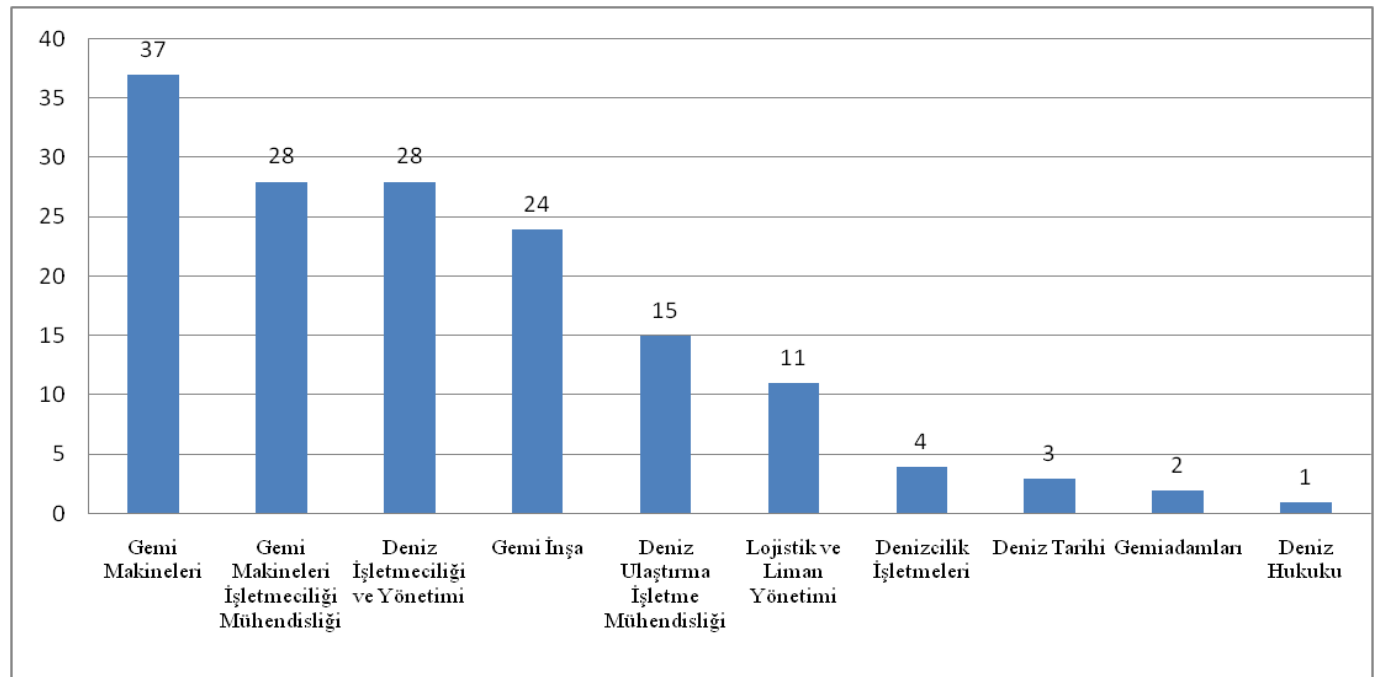

Şekil 8. Makalelerin Konu Başlıklarına Göre Sınıflandırılması

Makaleler konu başlıklarına göre incelendiğinde, Gemi Makineleri konusunda 37 adet makale yayımlanarak, en fazla makale yayımlanan alan Gemi Makineleri'dir. Deniz Hukuku konusunda 1 adet makale yayımlanarak, en az makale yayımlanan alan Deniz Hukuku'dur. Makalelerin konu başlığına göre yüzdesi incelendiğinde konusu Gemi Makineleri olan makalelerin \%24 ile en fazla orana sahipken daha sonra sırasıyla; Gemi Makineleri İşletmeciliği Mühendisliği \%18, Deniz İşletmeciliği ve Yönetimi \%18, Gemi İnşaa \% 16, Deniz Ulaştırma Mühendisliği \% 10, Lojistik ve Liman Yönetimi \% 7, Denizcilik İşletmeleri \% 3, Deniz Tarihi \% 2, Gemi Adamları \%1 ve Deniz Hukuku \%1 oranına sahiptir.

\subsection{Yıllara Bağlı Calıșma Konularındaki Eğilim} gösterilmiştir.

Yapılan araştırmada, yıllara göre en fazla çalışmanın yapıldığı 6 konunun dağılımı Tablo 4'te

\begin{tabular}{|c|c|c|c|c|c|c|c|c|}
\hline $\begin{array}{c}\text { Konular/ } \\
\text { Yillar }\end{array}$ & 2013 & 2014 & 2015 & 2016 & 2017 & 2018 & 2019 & 2020 \\
\hline $\begin{array}{c}\text { Gemi } \\
\text { Makineleri }\end{array}$ & 4 & 4 & 3 & 3 & 7 & 5 & 9 & 2 \\
\hline $\begin{array}{c}\text { Gemi } \\
\text { Makineleri } \\
\text { İşletmeciliği } \\
\text { Mühendisliği }\end{array}$ & 5 & 6 & 1 & - & 4 & 7 & 3 & 2 \\
\hline $\begin{array}{c}\text { Deniz } \\
\text { İşletmeciliği } \\
\text { ve Yönetimi }\end{array}$ & & 2 & 4 & 3 & 4 & 9 & 5 & 1 \\
\hline Gemi İnşa & - & 1 & - & 1 & 9 & 5 & 7 & 1 \\
\hline $\begin{array}{c}\text { Deniz } \\
\text { Ulaştırma } \\
\text { İşletme } \\
\text { Mühendisliği }\end{array}$ & - & - & - & 15 & - & - & - & - \\
\hline $\begin{array}{l}\text { Lojistik ve } \\
\text { Liman } \\
\text { Yönetimi }\end{array}$ & 2 & 1 & 2 & 3 & - & 1 & 2 & - \\
\hline
\end{tabular}

Tablo 4. Yıllara Göre Çalışma Konularının Eğilimi

2013 ve 2014 yıllarında, en fazla Gemi Makineleri İşletmeciliği Mühendisliği konusunda makale yayımlanırken, daha sonraki yıllarda bu konuda yayımlanan makale oranının düştüğü görülmektedir. 2015 yılında Deniz İşletmeciliği ve Yönetimi konusunda en fazla makale yayımlanmıştır. 2016 yılında, 
Deniz Ulaştırma İşletme Mühendisliği konusunda diğer konulardan daha fazla sayıda makale yayımlandığı görülmekte olup; bu konuda diğer yıllarda makale yayımlanmaması dikkat çekmektedir. 2017 yılında, 9 makalenin yayımlandığı Gemi İnşa konusunda yayımlanan makale sayısının artışında büyük bir ivme görülmüş ve bu yılda en fazla bu konuda makale yayımlanmıştır. 2018 yılında, 9 makalenin yayımlandığı Deniz İşletmeciliği ve Yönetimi konusu en çok makalenin yayımlandığı konu olmuştur. Gemi Makineleri konusunda 2019 yılında 9 makale yayımlanarak, bu konuda en fazla makale bu yılda yayımlanmıştır. 2020 yılına bakıldığında Gemi Makineleri ve Gemi Makineleri İşletmeciliği Mühendisliği konusunda 2'şer makale yayımlanmış olup, bu yılda en fazla makale bu iki konuda yayımlanmıştır.

\subsection{Makalelerde Kullanılan Araştırma Yöntemleri}

Nitel araştırmalarda, olaylara ve olgulara disiplinler arası bakışımız bir bütün şekilde olmalıdır. Çalışmalarda probleme bakış açımız, olay ve olgulara yüklenen anlamlar yorumlanır (Karataş, 2015). Nicel araştırmalar, nesnellik üzerine odaklanmış araştırmalardır. Araştırmalarda, değişkenlerin ölçülebilir verileri belirli bir metodla toplanıp, sonunda belirli metodlarla toplanan veriler analiz edilir (Queirós, Faria ve Almeida, 2017).

Araştırma sorularına, sadece nicel ve nitel yöntemi kullanarak cevap bulamıyorsak, karma yöntemi kullanırız. Karma yöntem, nicel ve nitel araştırma yöntemlerinin birlikte kullanıldığı bir araştırma biçimidir (Fırat, Yurdakul ve Ersoy, 2014).

Makaleler, araştırma yöntemi bakımından nicel, nitel ve karma olmak üzere 3 grupta sınıflandırılmıştır. Bu sınıflara göre makalelerden 92'sinde nicel, 44'ünde nitel ve 17'sinde karma araştırma yöntemi kullanılmıştır. Araştırma yöntemlerinin yüzdelik oranı Şekil 10'da görükmektedir.

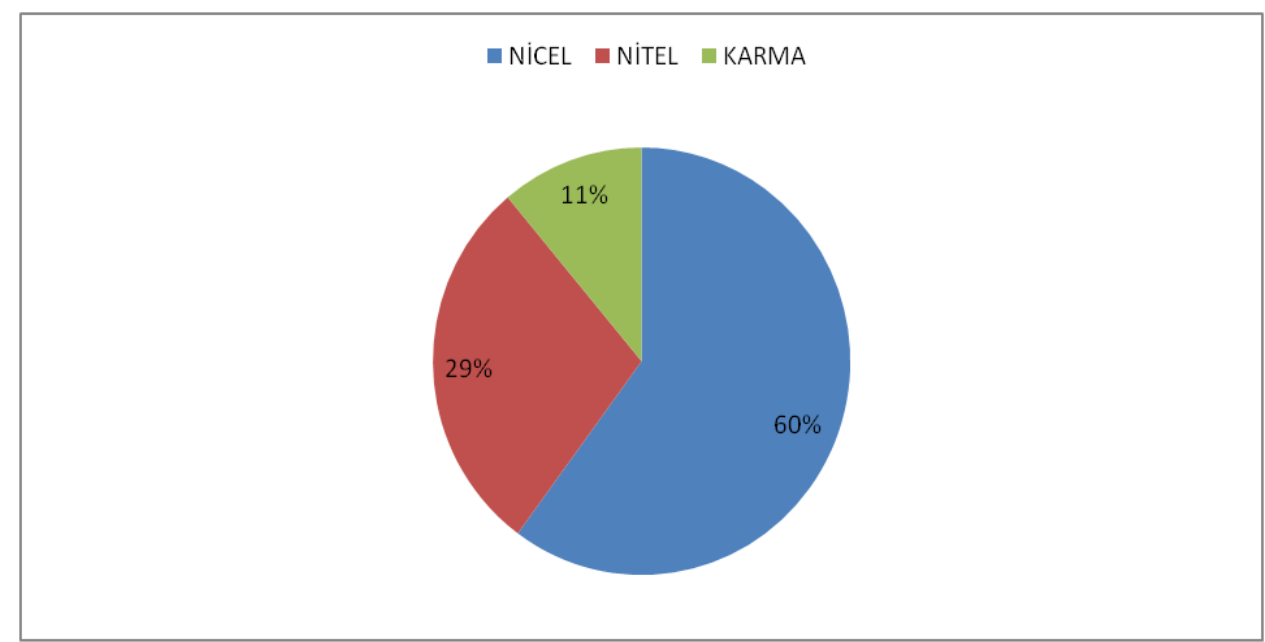

Şekil 9. Makalelerin Araştırma Yöntemlerine Göre Sınıflandırılması

Yayımlanan makalelerin \% 60’ında nicel araştırma yöntemi kullanılırken, \%29’unda nitel ve \%11'inde karma araştırma yöntemi kullanılmıştır. Makalelerde kullanılan araştırma yöntemlerinden nicel araştırma yönteminin, nitel ve karma araştırma yönteminden çok daha fazla olduğu görülmektedir.

\subsection{Makale Başılılarında Kullanılan Kelimelerin Frekansı}

Metinde kullanılan kelimelerin, kullanılma sıklığı ve metine kattığı anlam arasındaki bağlantıyı 1958 yılında ilk defa Luhn tanımlamıştır. Yapılan tanımlamada, frekansı yüksek olan kelimelerin dilin bütününü düşünerek cümleye ve metne anlam bakımından kattığı değer önemsizken, orta frekansta kullanılan kelimeler önemli olduğunun altı çizilmiştir. İçerik bakımından orta frekanslı kelimelerin önemli olduğu öne çıkarken, işlev bakımından ise yüksek frekanslı kelimlerin önemli olduğu öne çıkmaktadır (Metin, 2008). 

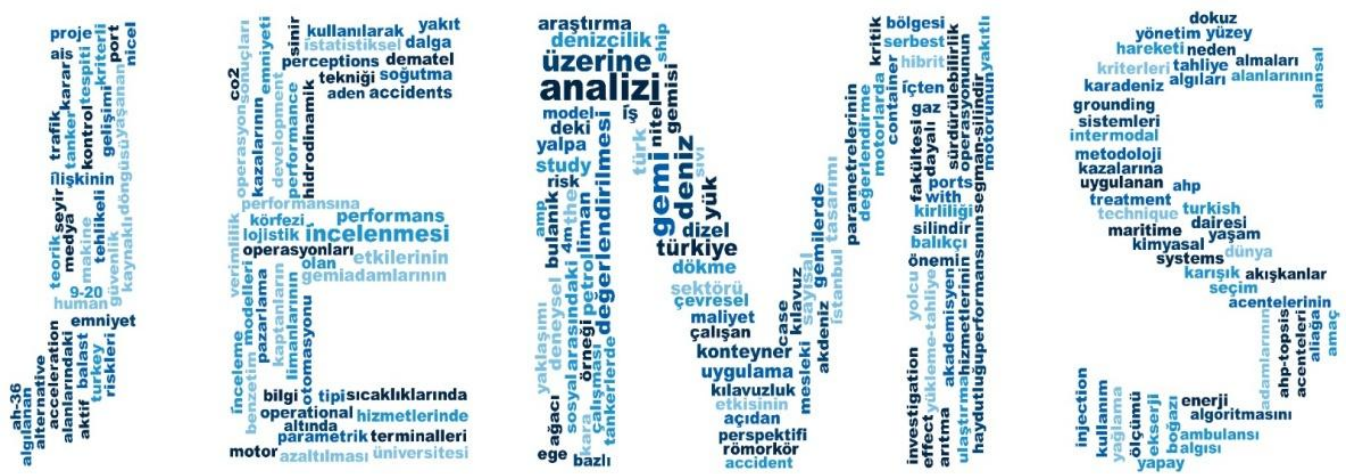

Şekil 10. Makale Başlıklarında Yer Alan Kelimelerden Oluşturulan Kelime Bulutu

Makale başlıklarında kullanılan kelimelerden kelime bulutu oluşturulup Şekil 11'de gösterilmiştir. Makale başlıklarında yer alan kelimeleri derginin amaç ve kapsam bakımından iki gruba ayırdığımızda; kapsam bakımından frekansı en yüksek "Gemi" kelimesini "Deniz" kelimesi takip etmektedir. "Gemi” kelimesinin frekans1 22 iken, “Deniz” kelimesinin frekansı 19'dur. Derginin kapsam bakımından kullandığı kelimelere baktığımızda frekansı en fazla olan kelime 19 frekansa sahip "Analizi" kelimesidir.

\subsection{Denizcilik Dergileriyle İlgili Yapılan Bibliyometrik Çalışmaların Karşılaştırılması}

JEMS Dergisi bibliyometrik analizi verileri dahil 3 dergide yayınlanmış 4 farklı çalışmanın verileri Tablo 5'te gösterilmiştir. 2013-2016 yıllarını kapsayan, JEMS Dergisi üzerinde daha önce yapılmış olan çalışmanın kısıtlı nitel veri analizi olduğu daha önceki bölümlerde belirtilmiştir.

\begin{tabular}{|c|c|c|c|c|c|}
\hline & $\begin{array}{c}\text { Çalışma } \\
\text { Yapıldığı } \\
\text { Dönem }\end{array}$ & $\begin{array}{c}\text { İnceleme } \\
\text { Yapılan } \\
\text { Makale } \\
\text { Sayısı }\end{array}$ & $\begin{array}{c}\text { Kullanılan } \\
\text { Kaynak } \\
\text { Sayısı }\end{array}$ & $\begin{array}{c}\text { Yazar } \\
\text { Sayısı }\end{array}$ & $\begin{array}{c}\text { Sayfa } \\
\text { Sayısı }\end{array}$ \\
\hline $\begin{array}{c}\text { Journal of Marime } \\
\text { Affairs (JOMA) }\end{array}$ & $2002-2019$ & 325 & 3 & 2 & 21 \\
\hline $\begin{array}{c}\text { Journal of ETA } \\
\text { Maritime } \\
\text { Science(A } \\
\text { Qualitative } \\
\text { Analysis) }\end{array}$ & $2013-2016$ & 52 & 26 & 2 & 12 \\
\hline $\begin{array}{c}\text { Journal of ETA } \\
\text { Maritime Science }\end{array}$ & $2013-2020$ & 153 & 20 & 2 & 16 \\
\hline Trans Nav Journal & $2007-2012$ & 401 & 20 & 2 & 5 \\
\hline
\end{tabular}

Tablo 5. Dergilerin Bibliyometrik Analiz Çalışmalarının Bilgileri

Yapılan çalışmalar karşılaştırıldığında, en uzun çalışma dönemini kapsayan ve en fazla sayfa sayısına sahip olan çalışma JOMA Dergisi’nin bibliyometrik analizidir. 401 makalenin incelemenin yapıldğı çalışma Trans Nav Dergisi'nin bibliyometrik analizi en fazla makale incelemesinin yapıldığ dergidir. JEMS Dergisi'nin bibliyometrik analizinde 153 makale incelenmiştir. 26 kaynak kullanımıyla en fazla kaynak JEMS Dergisi'nin nitel veri analizinde kullanılırken, JEMS Dergisi'nin bibliyometrik analizinde 20 kaynak kullanılmıştır. 21 sayfayla JOMA Dergisi'nin bibliyometrik analizi en fazla sayfayken, JEMS Dergisi'nin bibliyometrik analizi 16 sayfadır. Karşılaştırılan bibliyometrik çalışmaların hepsi 2 yazarlıdır.

\section{TARTIŞMA VE SONUÇ}

Bibliyometrik analizler, araştırma yapan kişilere araştırma yaptıkları alan ile ilgili özgün bilgiler sağlamaktadır (Polat, Sağlam, ve Sarı, 2013). Literatürde bulunan bilimsel çalışmalar, bibliyometrik yöntemlerle analiz edilerek, bilimsel eserlerin yayın esaslarına dair usullerin geliştirilmesine katkı 
sağlamaktadır (Al, Sezen ve Soydal, 2012). Türkiye'de yayınlanmaya başlayıp, ilk zamanlarda ulusal kimliği sahip olan JEMS dergisi zamanla uluslarası kimliğe de sahip olmuştur. JEMS dergisinin nitel içerik analiziyle ilgili sınırlı çalışmalar daha önce yapılmışken, detaylı bibliyometrik analiz çalışması yapılmamıştır. Bu konuda detaylı bir çalışmanın gerekli olduğu düşünülerek JEMS dergisinin bibliyometrik analizi yapılmıştır. Yapılan bu çalışmada JEMS dergisindeki 2013-2020 yıllarında yayınlanan 153 adet makelenin yazar profili, sayfa sayısı, kaynakça, kullanılan araştırma teknikleri, makalelerin yazı dili ve konu başlığı sınıflandırması gibi bibliyometrik parametrelerle incelenmesi sonucunda, derginin gösterdiği eğilim ve gelişimlerin ortaya çıkarılması amaçlanmıştır.

2013 yılında yayım hayatına başlayan dergi 2013, 2014 ve 2015 y1llarında yılda 2 sayı yayımlarken; 2016 yılında ve sonraki yıllarda, yayımladığı dergi sayısını 2 kat arttırarak yılda 4 sayı yayımlamaya başlamıştır. Yıllık dergi sayısındaki bu artış yayımlanan makale sayısınıda doğru orantılı olarak arttırmıştır. Yayımlanan makale sayısı 2016 yılı ve sonrasında 2 katı civarında artmıştır. Derginin yılda 2 sayı çıkardığı yıllarda en az makale sayısı yılda 14 iken, 4 sayı çıkardığı yıllarda en fazla makale sayısı yılda 29 tanedir. Bu aradaki farkın temel sebebi çıkarılan dergi sayısındaki artıştır.

Çalışmada, 343 yazarın incelemesi yapılmıştır. Yazar sayıları, 2016 yılı ve sonrasında yaklaşık 2 kat artmıştır. $\mathrm{Bu}$ durumun temel sebebi 2016 yılında ve sonraki yıllarda derginin yıllık yayımlanma sayısının 2 katına çıkarılmasıdır. Yazar cinsiyet oranlarına baktığımızda \%83'ünün erkek, \%17'sinin kadın araştırmacı olduğunu görmekteyiz. $\mathrm{Bu}$ durumun denizcilik sektöründe ve denizcilik araştırmalarında erkeklerin sayısının kadınların sayısından çok daha fazla olmasından kaynaklandığını söyleyebiliriz.

$\mathrm{Bu}$ çalışmada yazar kurumları incelendiğinde en fazla yazarın olduğu ilk 5 kurum sırasıyla; Dokuz Eylül Üniversitesi, İstanbul Teknik Üniversitesi, Yıldız Teknik Üniversitesi, Karadeniz Teknik Üniversitesi ve Piri Reis Üniversitesi olduğunu görülmektedir. Bu üniversitelerin hepsinde Denizcilik Fakültesi olduğu görülmekte ve denizcilik sektörüne hizmet verecek iş gücü sağlamaktadır. Akademik bir dergi olan JEMS Dergisi akademik makaleler yayımlamaktadır. Bunun sonucunda yazarların büyük çoğunluğunun üniversitelerdeki akademisyenlerden olduğu görülmektedir. Yazar unvanlarına bakıldığında 10 yazar dışında diğer yazarların unvan belirtmediği görülmüştür. Bu unvanların bir çoğuda 2013 ve 2014 yıllarında yayınlanan makaleler olduğu görülmektedir. 2017 yılında ve sonraki yıllarda yayınlanan makalelere ORCID numaraları eklendiği görülmüştür. $\mathrm{Bu}$ numaralar sayesinde yazar bilgilerine ulaşılması dahada kolaylaşmıştır.

Alıntı yapılan eser, yeni oluşturulan yayını organik bir bağ ile besleyebilirse, atıf yapmanın en önemli unsuru sağlanabilmiş demektir. Atıf sayısının artmasıyla daha kaliteli eserlerin ortaya çıkması ve farklı kaynaklardan beslenen yayının literatürdeki etkisinin artması beklenir (Çetin ve Çaylan, 2014). Yapılan çalışmadaki makalelerin kaynakça sayısına bakıldığında toplam kaynakça sayısı 4117 iken makale başına düşen kaynakça sayısı 26,9 olduğu görülmektedir. 2013 ve 2014 yılında makale başına kullanılan kaynak sayısı 11,1 ve 14,3'tür. $\mathrm{Bu}$ yıllarda kullanılan kaynak sayısının az olduğunu söyleyebiliriz.

Yapılan çalışmada kullanılan yazı dili incelendiğinde derginin Türkçe ve İngilizce yazı dilini kullandığı görülmektedir. 2018 yılına kadar yayımlanan makalelerde Türkçe yazı dili kullanımı İngilizce yazı dili kullanımından fazla olduğu görülmektedir. Bu durum 2018 ve sonrasında değişmiştir. 2018 yılında İngilizce makale sayısı Türkçe makale sayısına eşitttir. 2019 yılında ise İngilizce makale sayısı Türkçe makale sayısını geçmiştir. 2020 yılında ise derginin yazı dilinin komple İngilizce olduğu ve sadece İngilizce makalelere yer verildiği görülmektedir. 2020 yılında komple İngilizce yazı diline geçmesiyle dergi uluslararası bir kimlik kazanmıştır. Bunun sonucunda, makale yazarları içinde yabancı araştırmacı sayısının arttı̆̆ıda görülmektedir.

Makaleler, dergi tarafından 8 konu başlığı altında toplanmaktadır. Bu konu başlıkları; Lojistik ve Liman Yönetimi, Gemi Makineları İşletme Mühendisliği, Deniz Ulaştırma ve İşletme Mühendisliği, Deniz İşletmeleri ve Yönetimi, Gemi İnşa, Deniz Tarihi, Gemiadamları ve Deniz Hukuku' dur. Bu makalelerden en fazla sayıya Lojistik ve Liman Yönetimi konulu makaleler yazılmıştır. Daha sonra buna yakın sayıya sahip Deniz Mühendisliği ve Deniz Ulaştırma Mühendisliği konulu makaleler yer almakatadır. Yayınlanan makaleler daha çok denizciliğin işletmecilik ve mühendislik kısmına ait olduğu görülmüştür. Dergi, her ne kadar Gemi Makineları Mühendisleri Odası tarafından yayımlansada, içerdiği konular denizcilikle alakalı gemi makinaları dışında bir çok konuyu içermektedir. 
Makale konularının yıllara göre eğilimi incelendiğinde, son yıllarda Gemi Makineları ve Gemi İnşa konusunda yayımlanan makale sayısının arttığı görülmektedir. Lojistik ve Liman Yönetimi konusunda, yayımlanan makale sayılarının yıllara göre daha stabil olduğu görülmektedir.

Dergide yayımlanan makalelerde kullanılan bilimsel araştırma yöntemleri incelendiğinde makalelerin \%60'1 nicel, \%29'u nitel ve \%11'i karma araştırma yöntemlerinin kullanıldı̆̆ görülmektedir. Yapılan çalışmalar daha çok mühendislik ve yönetim alanında olmasından dolayı nicel araştırma tekniğinin oranı diğerlerinden çok daha fazladır.

Makale başlıklarında kullanılan kelimelerin kelime frekanslarına bakıldığında, en çok kullanılan kelimenin 30 frekansa sahip olan "analizi” kelimesi olduğu görülmektedir. Yapılan çalışmaların analiz üzerine yapılması ve bunun başlıkta belirtilmesi analizin en çok kullanılan kelime olmasını sağlamıştır. "Gemi" ve "Deniz" kelimeleri ise denizcilik sektörü ile ilgili çok sık kullanılan kelimeler olduğundan ve derginin kapsamı bakımından kullanılan kelimeler olduğudan frekansları diğer kelimelere göre fazladır.

\section{Çalışmanın Kısıtları ve Gelecek Çalışmalar Için Öneriler}

Çalışmada değerlendirilen makaleler sadece 2020 yılının 1 nolu dergisinde ve ondan önce yayınlanan dergilerdeki çalışmaları içermektedir. Bunun nedeni JEMS Dergisi 2020 yılının 1. sayısından sonra Web of Science ESCI tabanında yer almaya başlamıştır. Bu yüzden daha sonra yayımlanan dergiler, bu çalışmaya dahil edilmemiştir.

Gelecekte bu konuyla ilgili yapılacak çalışmalarda Web of Science ESCI öncesinde ve sonrasında yayımlanan çalışmalar diye ikiye ayrılarak bibliyometrik analiz yapılabilir.

Bu çalışmanıın en önemli kısıtı, bibliyometrik analizin sadece bir dergide yer alan çalışmalara yönelik yapılmış olmasıdır. İleriki araştırmalara yönelik olarak denizcilik alanında yayın yapan birden fazla dergi içinde yapılan bibliyometrik analizlerinin sonuçlarının karşılaştırılması ve ayrıca söz konusu derginin ESCI indeksinde tarandıktan sonraki yayınladığı çalışmaların bibliyometrik sonuçları ile daha önceki sonuçlarının karşılaştırılması da önerilebilir.

\section{KAYNAKÇA}

Al, U. (2008). Türkiye'nin Bilimsel Yayın Politikası: Atif Dizinlerine Dayalı Bibliyometrik Bir Yaklaşım, (Yayımlanmamış Doktora Tezi), (Danışman: Prof. Dr. İrfan Çakın), Ankara: Hacettepe Üniversitesi Sosyal Bilimler Enstitüsü.

Al, U.; Sezen, U. ve Soydal, İ. (2012). Türkiye’nin Bilimsel Yayınlarının Sosyal Ă̆ Analizi Yöntemiyle Değerlendirilmesi, (Proje No: 110K044). Ankara: Hacettepe Üniversitesi Bilgi ve Belge Yönetimi Bölümü.

Bozkurt, Ö. Ç. ve Çetin, A. (2016). Girişimcilik ve Kalkınma Dergisi’nin Bibliyometrik Analizi. Girişimcilik ve Kalkınma Dergisi, 11(2), 229-263.

Çetin, Ç. K. ve Çaylan, D. Ö. (2015). Stratejik Yönetim Yazınının Entelektüel Yapisinda Değişim: 20012013 Yilları Arası Bibliyometrik Bir Değerlendirme. Atatürk Üniversitesi İktisadi ve İdari Bilimler Dergisi, 29(1), 101-120.

Ertekin, C. (2014). Bilimsel Araştırma ve Bilimsel Performans Ölçümü. Türk Nöroloji Dergisi, 20(2), 3236.

Fırat, M.; Yurdakul I. K. ve Ersoy, A. (2014). Bir Eğitim Teknolojisi Araştırmasına Dayalı Olarak Karma Yöntem Araştırması Deneyimi. Eğitimde Nitel Araştırmalar Dergisi, 2(1), 65-86.

Fışkın, R. ve Nas, S. (2013). A Content Analysis of the International Journal on Marine Navigation and Safety of Sea Transportation from 2007 to 2012. Transnav, 7(1), 145-149.

Fışkın, C. S. ve Cerit, A. G. (2020). Comparative Bibliometric and Network Analysis of Maritime Transport/Shipping Literature Using the Web of Science Database. Scientific Journals of the Maritime University of Szczecin, 61(133), 160-170.

Fışkın, R. ve Nas, S. (2016). A Qualitative Analysis of Journal of ETA Maritime Science (JEMS) and Its Management Process. Journal of ETA Maritime Science, 4(4), 343-354.

Hotamışlı, M. ve Erem, I. (2014). Muhasebe ve Finansman Dergisi'nde Yayınlanan Makalelerin Bibliyometrik Analizi. Muhasebe ve Finansman Dergisi, 0(63), 1-20.

Karagöz, B. ve Koç Ardıç, İ. (2019). Ana Dili Eğitimi Dergisinde Yayımlanan Makalelerin Bibliyometrik Analizi. Ana Dili Ë̆itimi Dergisi, 7(2), 419-435.

Karataş, Z. (2015). Sosyal Bilimlerde Nitel Araştirma Yöntemleri. Manevi Temelli Sosyal Hizmet Araştırmaları Dergisi, 1(1), 62-80. 
Kayakıran, D. ve Doğan, S. (2019). Maliye ve Finans Yazıları Dergisi’nde Yayımlanmış Makalelerin Bibliyometrik Analizi (2008-2019). Ekonomi Maliye İşletme Dergisi, 2(2), 92-102.

Metin, S. (2008). Türkçede Kullanılan İşlev Kelimelerinin ZIPPF 1. Kanunu Esasında Değerlendirilmesi. Gazi Üniversitesi Mühendislik Mimarlık Faültesi Dergisi, 23(2), 467-475.

Polat, C.; Sağlam, M. ve Sarı, T. (2013). Atatürk Üniversitesi İktisadi ve İdari Bilimler Dergisi'nin Bibliyometrik Analizi. Atatürk Üniversitesi İktisadi ve İdari Bilimler Dergisi, 27(2), 273-288.

Polat, C.; Sağlam, M. ve Sarı, T. (2013). Atatürk Üniversitesi Güzel Sanatlar Fakültesi "Sanat" Dergisi'nin Bibliyometrik Analizi. Sanat Dergisi, 0(23), 9-26.

Queirós, A.; Faria, D. ve Almeida, F. (2017). Strengths and Limitations of Qualitative and Quantitative Research Methods. European Journal of Education Studies, 3(9), 369-387.

Sahoo, S. ve Schönborn, A. (2020). A Bibliometric Overview of WMU Journal of Maritime Affairs Since Its Inception in 2002. WMU Journal of Maritime Affairs, 19(5), 5-25.

Snodgrass, R. (2007). Single-Versus Double-Blind Reviewing. ACM Journals, 32(1), 1-31.

Şakar, G. ve Cerit, G. (2013). Uluslararası Alan İndekslerinde Türkiye Pazarlama Yazını: Bibliyometrik Analizler ve Nitel Bir Araştırma. Atatürk Üniversitesi İktisadi ve İdari Bilimler Dergisi, 27(4), $37-62$. 
